\title{
Artelogie
}

artelogie Recherche sur les arts, le patrimoine et la littérature de l'Amérique latine

$9 \mid 2016$

Horizons et perspectives de la culture en Colombie (1990-2015)

\section{Clase, etnia y región: el Caribe Novogranadino y la mirada del "Otro". 1750-1830}

Leguis A. Gómez

\section{OpenEdition}

\section{Journals}

Edición electrónica

URL: http://journals.openedition.org/artelogie/298

DOI: 10.4000/artelogie.298

ISSN: 2115-6395

Editor

Association ESCAL

Referencia electrónica

Leguis A. Gómez, "Clase, etnia y región: el Caribe Novogranadino y la mirada del "Otro". 1750-1830», Artelogie [En línea], 9 | 2016, Publicado el 20 junio 2016, consultado el 17 noviembre 2020. URL : http:// journals.openedition.org/artelogie/298; DOI : https://doi.org/10.4000/artelogie.298

Este documento fue generado automáticamente el 17 noviembre 2020

Association ESCAL 


\title{
Clase, etnia y región: el Caribe Novogranadino y la mirada del "Otro". 1750-1830
}

\author{
Leguis A. Gómez
}

\section{INTRODUCCION}

1 La idea de la nación que se imaginó construir la elite criolla en el caso de la Nueva Granada, buscó crear un paralelo aceptable dentro del imaginario de los círculos científicos y académicos europeos de la época. La correlación de ideas entre científicos como Alexander Von Humboldt, José Celestino Mutis y Francisco José de Caldas, evidenciada en sus escritos, muestra un pensamiento homogéneo en relación con el espacio geográfico de las regiones en la Nueva Granada y sus habitantes (Pratt, 1992). En esa búsqueda, todo aquello que no encajaba en la uniformidad, sencillamente no hacía parte del imaginario a construir (Anderson, 1991). El Caribe Novogranadino se convirtió así, en un espacio de frontera (Barth, 2000; Garliz, Jiménez, 2012) no solo por las dificultades geográficas de la Nueva Granada, que lo separaban del gobierno centralizado en Bogotá, sino también por sus habitantes, que lejos de ser considerados como futuros sujetos de la nación en ciernes, fueron excluidos entre otras razones, por su color de piel y su mezcla étnica. (Benitez Rojo, 1996). El sujeto con el que se creó la idea del ciudadano, fue eminentemente blanco y andino, emulando así al de Europa (Hobsbawm, 2000; Annino y Guerra:2003; Ramos, 2013:139).

2 En este trabajo se presenta un análisis de las percepciones que personajes como Humboldt, Mutis, Caldas y otros viajeros que visitaron el Caribe Novogranadino durante el período de este estudio, dejaron plasmadas en sus memorias de viaje. La revisión de sus escritos, muestra cómo se construyó la imagen de la región, en comparación con el centro andino, así como de sus habitantes, mostrándola al mundo académico como una región de frontera, dispersa, inhóspita e infernal y cuyos habitantes y sus conductas arraigadas histórica y culturalmente, les indicaban a los 
visitantes, que no podían ser parte de la civilización conocida hasta ese momento. El advenimiento de la nación colombiana, alejó a la región y a sus habitantes del concierto de las naciones al considerarlos un Otro que no cabía dentro del imaginario aceptado internacionalmente. La mirada del otro se ha manifestado de dos formas. Por un lado, los viajeros se han valido de diarios y relatos de viaje en los cuales han anotado sus experiencias y visiones durante el término de su viaje o bien algunos años después del mismo. Por otro lado, los documentos de la experiencia de funcionarios son una fuente valiosa del modo en que éstos han construido a través de imágenes y discursos, sus visiones de la sociedad colombiana durante la época en cuestión.

El artículo está dividido en dos partes. La primera aborda las descripciones que sobre la región del Caribe Colombiano dejaron plasmadas los personajes aquí estudiados a través de sus memorias y diarios de viajes. La segunda parte, analiza sus percepciones sobre los habitantes de la región.

\section{En un mundo inhóspito y entre salvajes}

Los extranjeros han tenido un papel importante en la historia colombiana. Por un lado, la propia estructura de dominación colonial se fundamentó en la presencia de funcionarios en el manejo de la colonia, a través del control de la esfera burocrática, religiosa y militar, así como en el control del comercio. El periodo colonial atrajo también a un sinnúmero de personas al Nuevo Mundo y la Nueva Granada no escapó a estas visitas, entre estas, no pocos fueron científicos que llevaron a cabo importantes expediciones, como la de José Celestino Mutis junto a Francisco José de Caldas o la de Alexander Von Humboldt; los religiosos que establecieron sus misiones con el fin de llevar la palabra cristiana a todos los habitantes y de paso adoctrinarlos en la fe católica y otros viajeros diplomáticos y exploradores, como lo fue el caso del notable geógrafo francés Eliseo Reclus en su intención de elaborar un compendio de geografía universal.

Cada uno de estos sectores dejó grabadas sus impresiones sobre la sociedad a la cual asistían como espectadores. No obstante el hecho de ser espectadores, no pocos de los que observaron las manifestaciones culturales que se vivían en esas sociedades se convirtieron en jueces no siempre imparciales de lo que presenciaron.

El proceso que sigue, en el que se subvierten muchas de las normas y virtudes de las que el viajero está formado, lo obliga a pretender universalizar las virtudes de la sociedad a la que pertenece y al hacerlo se vuelve en palabras de Todorov un etnocentrista (Todorov, 2000:21). Esto es, al no poder encontrar las virtudes de donde proviene en las manifestaciones sociales que observa, entonces procede a separar, excluir, diferenciar y discriminar a los Otros, los que no encajan en su orden de valores.

7 Si bien el proceso de universalizar valores de procedencia del observador termina por ubicarlo en una posición preeminente sobre "los otros", no se puede olvidar que no siempre el observador reconoce los vicios de la sociedad a la que pertenece, más bien los oculta y aunque en su fuero interior sepa y esté acostumbrado a observar los mismos males que ahora aparecen supuestamente nuevos ante sus ojos, dos son los estándares con los que opera:con uno mide su propia sociedad y con otro la sociedad que en sus viajes visita y con la cual, indudablemente, es más intolerante y rígido (Garlan, 1984:141-145). 
8 Nosotros somos mejores que los otros, parece ser el pensamiento recurrente en el comportamiento del observador (quien así mismo es un Otro frente a los observados) y también la vara de la medida con la cual se compararán incesantemente los comportamientos de los habitantes de los distintos lugares donde el ojo del observador foráneo centra su atención, fenómeno social que, dicho sea de paso, también se experimentó entre los habitantes del Caribe colombiano, así como de la región que habitaban.

El "Otro" es por definición, sujeto de atribuciones categóricas directamente proporcionales a lo que no se encuentra en él por parte de quien lo observa. Con otras palabras, sobre el "Otro" recaen categorías contrarias a las que supuestamente posee el observador e interlocutor. Así, a la categoría de civilizado, se le opone la de bárbaro. La categoría de bárbaro denota concepciones de crueldad, salvajismo e incluso primitivismo atribuibles, tal como se verá en este caso a los habitantes del Caribe Colombiano.

Igualmente, como sugiere Francisco Fernández Buey, el bárbaro también es por definición inferior, culturalmente hablando (Fernández Buey, 1995:1-2). Una lectura de las concepciones plasmadas por los viajeros y funcionarios españoles en la Nueva Granada, muestra perfectamente el orden de atribuciones categorizantes aquí mencionado. Tal como lo sugiere Irving A. Leonard, lejos de ser una experiencia ilustrativa para el viajero o funcionario, visitar el Nuevo Mundo se convirtió en un proceso que no muchos deseaban repetir, dados los sufrimientos y peligros a los que estaban expuestos según sus memorias y demás escritos (Leonard, 1992:1s). De ahí que frente a una experiencia negativa ante la larga y extenuante travesía, la pérdida de tiempo, los cambios climáticos, el comportamiento "no civilizado" de los habitantes de la región, y en fin, frente a la novedad de lo desconocido, sea lógico pensar en la posibilidad de la pretendida opción por universalizar lo propio frente a lo extraño (Morner, Jaramillo, 2002).

11 Por otro lado, el viajero trae consigo su propia historia. No se trata en lo absoluto de un sujeto de mirada objetiva, limpia, algo así como una hoja de papel sin timbre, o tabula rasa. Por el contrario, llega a los distintos lugares que vista cargado de sus propias visiones sobre el mundo, con objetivos establecidos antes de su llegada. Es decir, se trata de un actor con su libreto, a través del cual "lee" el nuevo ambiente que le rodea y que se apresta a descubrir. No se trata apenas de una lectura seca, de una narración pre establecida:en su viaje el viajero irá descubriendo los desafíos entre su visión de mundo y la realidad ante la que se encuentra, de hecho, su mirada manifiesta su extrañeza y hasta su rechazo ante el espectáculo social y cultural que se presenta ante sus ojos.

12 A mediados del siglo XVIII, los intentos borbónicos por controlar un imperio que se había mantenido independiente gracias a las distancias, lo accidentado de la geografía y a las características particulares de desempeñar y ejecutar las órdenes que provenían desde la metrópolis ibérica, provocaron una inestabilidad que acabaría por polarizar las posiciones de los grupos dominantes criollos en las colonias. Si bien los intentos borbónicos por lograr consolidar su poder y de paso "des-americanizar" el imperio, desestabilizaron el orden colonial, por otro lado llevaron a cabo una tarea que sirvió para conocer cuáles eran las riquezas del medio geográfico que se gobernaba. El despotismo ilustrado, como se ha conocido el régimen, ayudó a desarrollar proyectos de corte científico que intentarían conocer de qué forma estaban constituidas las colonias, con el fin de administrarlas mejor (Lynch, 1991). 
13 En el imaginario que sobre el Nuevo Mundo generó en Europa a raíz del descubrimiento, se tejieron numerosas versiones sobre las nuevas tierras y sobre quienes las habitaban, de tal manera, que la construcción histórica que sobre ellas se hizo, estuvo en todo momento matizada por los ideales que sobre las nuevas tierras se habían creado en Europa (Bitterli, 1982; Fernández Buey, 1995; Hurbon, 1993; Zea, 1990).

14 Uno de los proyectos más ambiciosos llevados a cabo, paralelo a la famosa labor iniciada por Humboldt, fue la Real Expedición Botánica del Nuevo Reino de Granada, dirigida por el sabio José Celestino Mutis. En dicha expedición llevada a cabo entre 1783 y 1806, Francisco José de Caldas, discípulo de Mutis y conocido en Colombia como "el sabio Caldas", fue quien emprendió bajo la supervisión de su mentor y albacea, los viajes a lo largo y ancho del virreinato con el fin de consolidar la expedición. En uno de sus escritos, cuyos efectos llevaron a una encarnizada discusión con otros científicos de la época, afirmó lo siguiente :

Un calor abrasador y constante (de $27^{\circ}$ á $30^{\circ}$ Reaumur) reina en las llanuras que hacen basa a esta soberbia (tierra). El hombre que habita estas regiones se desarrolla con velocidad y adquiere una estatura gigantesca, pero sus movimientos son lentos, y una voz lánguida y pausada unida a un rostro descarnado y pálido anuncia que estas regiones no son las más ventajosas para el aumento de la especie humana. (...) Esta es la patria del mosquito insoportable y de esos ejércitos numerosos de insectos, entre los cuales unos son molestosos, otros inocentes, otros brillantes, aquellos temibles. Las aguas cálidas de los ríos anchurosos, están pobladas de peces, y en sus orillas viven..., mil lagartos de escalas diferentes, y el enorme cocodrilo (caimán) ejerce sin rival un imperio tan ilimitado como cruel. (CALDAS, 1912)

Del texto se desprende la admiración que sentía Caldas por las dimensiones físicas de los habitantes de la región, al mismo tiempo convenía en que estas mismas complexiones daban a entender, contradictoriamente, que en la misma región (y pese a un desarrollo físico admirable ¡), la vida no podía generarse adecuadamente. Caldas era igualmente inconsciente de que al afirmar tan vehementemente sus apreciaciones sobre el clima, la vegetación, la fauna y los seres humanos que habitaban la región, perdía de vista la noción de cientificidad, para darle cabida en su discurso a percepciones que nada tenían de científicas, entre otras razones, porque Caldas abiertamente rechazaba con sus palabras al hombre tropical. Víctima de las concepciones muy en boga sobre la cuestión del determinismo geográfico en la complexión y el comportamiento de los seres, nuestro personaje no se daba cuenta que sus apreciaciones eran demasiado generales para seguir sosteniendo sus argumentos. No obstante, Caldas no opinaba lo mismo de la región andina del interior del país, debido principalmente a que se le asemejaba mejor a Europa :

La región media de los Andes...con un clima dulce y moderado...produce árboles de alguna elevación, legumbres, hortalizas saludables, mieses; todos los dones de Ceres:hombres robustos, mujeres hermosas, bellos colores son el patrimonio de ese suelo feliz. Lejos del veneno mortal de las serpientes; libres del molesto aguijón de los insectos, pasean sus moradores los campos y las selvas con entera libertad. El buey, la cabra, la oveja, le ofrecen sus despojos y le acompañan en sus fatigas. El ciervo, la danta..., el oso, el conejo,.etc, pueblan los lugares a donde no ha llegado el imperio del hombre. (CALDAS, 1912).

16 El hombre y la mujer de la región media de los Andes, a diferencia de los habitantes de la región caribeña colombiana, tenían mejor aspecto, según Caldas y al mismo tiempo, el suelo que pisaban, de por sí solo, al parecer les daba felicidad, cosa que los habitantes 
de la costa no podían soñar ante tanto animal salvaje acechándolos y ante un clima abrasador.

Francisco José de Caldas, personaje de una pasión desbordante por la ciencia y de un ánimo que admirarían otros científicos de la época, recorría con el mismo esfuerzo y empuje al camino desde Bogotá hasta Quito, o bien desde la capital hasta la costa pacífica colombiana, e incluso hasta la atlántica (caribeña). (Caldas, 1966). Si bien Caldas se mostraba partidario de la autonomía de la Nueva Granada frente el gobierno español, su labor, llevada a cabo ante a representantes del gobierno real, lo obligaba a responder vehementemente a las exigencias que el proyecto de la expedición botánica le planteaba. Sus escritos muestran hasta qué punto sentía que debía estar al lado de otros científicos como Mutis y Humboldt, a quienes admiraba, para poder aprender nuevos conocimientos que en la Nueva Granada no se tenían. De hecho, en sus cartas a Mutis constantemente se quejaba de la falta de preocupación por parte de los gobiernos de turno, de implementar espacios donde el conocimiento pudiera desarrollarse efectivamente. Por ello, sus descripciones sobre el espacio que observaba las hacía de manera tan esforzada, pues quería mostrar a los científicos que llevaban a cabo la expedición (Mutis e incluso Humboldt), que en la Nueva Granada sí había gente dispuesta no solo a aprender sino, también a desarrollar y producir conocimiento.

Así pues, Caldas persiguió un aprendizaje del país que lo vio nacer cobijándose en los conocimientos que personajes como Humboldt y Mutis podían proporcionarle. Ello le permitió conocer las distintas caras que componían su patria, al tiempo que lograba identificar la realidad de la Nueva Granada en su conjunto:

Si hacemos notar la diferencia que hay en el carácter, en los gustos, en las pasiones, entre el habitante de los climas ardientes y el que vive sobre los andes; si formamos, en general, el cuadro de estas diferentes temperaturas y del hombre que las habita, habremos llenado nuestro objeto. (CALDAS, 1912:302).

Con estas palabras, expresaba Caldas el interés principal de su estudio que consistía en centrar su atención en búsqueda de cómo estaba compuesta entonces la Nueva Granada, aunque ya tuviera claro que sólo en las regiones templadas, como la de los Andes, la vida fuera más fácil de ser vivida.

La contraposición de climas, caracteres y modos de vida, parece ser, desde la perspectiva de Caldas, el mejor medio para salvaguardar su propio estilo de vida, que era, en últimas, más civilizado al compararlo con los de los habitantes de las zonas tropicales del virreinato:

¿Cuáles son las pasiones, cuáles las virtudes, cuál el carácter del hombre que habita estas regiones? (...) Sus mujeres en poco se distinguen de los hombres. La belleza, los rasgos delicados que distinguen su sexo en los demás pueblos de la tierra, aquí parece que faltan. Los pechos, la voz y un trozo de lienzo envuelto á la cintura son los únicos caracteres exteriores que las distinguen. Si los rasgos varoniles de su fisonomía las acercan a los hombres, sus ejercicios las confunden con ellos. Carga, recorre, nada, navega con la misma intrepidez y valentía; va a la pesca y sigue al marido á la caza. Es verdad que no se arma ni ataca á las fieras con valor; pero ve los combates con semblante sereno y sin estremecerse. (CALDAS, 1912:302).

Estas reflexiones sobre la mujer del trópico se mantenían unidas directamente a su visión general sobre los habitantes de la región en cuestión, pero se puede afirmar que Caldas era incluso más severo con la mujer que con el hombre. Esto debido a que Caldas no escapaba a la visión complementaria del rol que debía mantener ésta en relación con el varón. En las reflexiones de Caldas, claramente se puede notar su predilección por el 
rol secundario que debía ocupar la mujer con respecto al hombre. Cualquier gesto $u$ actividad que se saliera de lo "normalmente" aceptado por la sociedad de donde él procedía, que dicho sea de paso, era la andina, le generaba cierto rechazo que no ocultaba en lo absoluto.

Por su parte, refiriéndose al hombre anotaba:

El mulato se distingue del indígena sin mezcla por muchos rasgos característicos. Es alto, bien proporcionado, su paso firme...su semblante serio, el mirar oblicuo y feroz; casi desnudo, apenas cubre las partes que dicta la decencia...Intrépido, arrostra todos los peligros y se arroja con alegría sobre un leño en medio de un mar tempestuoso...Las serpientes, estos reptiles que inspira(n) el terror en todos los corazones, apenas conmueven el suyo. Mil veces a triunfado de sus dardos venenosos con las yerbas que tiene a la mano y cuyas virtudes conoce. (CALDAS, 1912:304).

La admiración que sentía Caldas sobre el coraje, la valentía y la constitución física del mulato contrastaban, paradójicamente, con el resultado que ejercían sobre él. Es decir, además de generarle temor y hasta cierta envidia por conocer cosas que Caldas desconoce (virtudes de las yerbas), al parecer no existe o no podía existir relación entre el coraje (propio del mulato) y la pasividad del hombre citadino. Su discurso sobre el hombre y la región, lejos de ser homogéneo, mostraba contradicciones relacionadas con la sensación de rechazo y la admiración frente a un espacio y a unos seres que probablemente no sólo a él, sino a otros viajeros, les resultaban igualmente lleno de perplejidades. Sin embargo, Caldas tenía una agenda en mente relacionada con la idea de mostrar una imagen del Caribe distinta a la del interior del país y a renglón seguido reflexionaba consecuentemente lo siguiente:

Cuando la sociedad en que vive quiere poner freno a sus deseos,...entonces vuelve sus ojos á los bosques tutelares de su independencia. Cuatro tiestos, una red, una hacha, su cuchilla y su lanza se colocan con velocidad sobre la barca, adonde le siguen su esposa y su familia:rema, atraviesa el laberinto de canales que forman los ríos hacia su embocadura, se hunde después en las selvas, y se arranca para siempre de una sociedad que coartaba sus deseos, ó que castigaba sus delitos. El carácter duro que lo distingue lo conserva hasta en sus amores. No son los halagos, no los servicios los que aseguran las conquistas. Un mono, un saíno, un armadillo ó un pescado ofrecido con fiereza, unas miradas menos duras, alguna vez promesas y aun amenazas, son los resortes que pone en movimiento. Apenas se ha hecho dueño de un corazón, dicta leyes severas, cuya transgresión castiga con la muerte ó con las más duras penas. Este es un tirano, aquella una infeliz. (CALDAS, 1912:306).

Si esta era la percepción sobre el hombre y la mujer del trópico, conviene igualmente mirar como percibió a los habitantes de la región de donde procedía:

Estos son más blancos y de carácter más dulce. Las mujeres tienen belleza, y se vuelven á ver los rasgos y los perfiles delicados de este sexo. El pudor, el recato, el vestido, las ocupaciones domésticas recobran todos sus derechos. Aquí no hay intrepidez, no se lucha con las ondas y con las fieras. Los campos, las mieses, los rebaños, la dulce paz, los frutos de la tierra, los bienes de una vida sedentaria y laboriosa están derramadas sobre los Andes. Un culto reglado, unos principios de moral $y$ de justicia, una sociedad bien formada y cuyo yugo no se puede sacudir impunemente, un cielo despejado y sereno, un aire suave, una temperatura benigna, ha producido costumbres moderadas y ocupaciones tranquilas. (CALDAS, 1912:306).

24 Nótese la tendencia de Caldas a creer que el clima, la vegetación, el carácter y las costumbres de la región de donde él procede, responden más a la idea de una sociedad civilizada donde las reglas ejercen un imperio que nadie puede sobrepasar, cosa que, dicho sea de paso, no sucedía en el trópico y algo tal vez más contradictorio aún, el 
clima del trópico ejercía o provocaba cambios físicos en las mujeres, lo cual deformaba su belleza, acercándolas a los hombres del Caribe Novogranadino, ya de por sí feos para Caldas (Munera, 1998:38; Todorov, 1991. De hecho, no necesariamente Caldas estaba lejos de tener la razón sobre la existencia de familias con marcada diferencia entre las que se formaban en la costa del Caribe Novogranadino, y las del interior del país andino (Castro, 1996); pero ese tipo de aceptación de la existencia de una Otredad más allá de las montañas, no era precisamente el asunto que ocupaba la mente de este personaje, pues, como se ha dicho en líneas anteriores, otra era su intención. ¿Con estas percepciones, será posible creer que se pudiera considerar la idea de una nación conformada e integrada por todos los que la habitaban?

Caldas no podía, aunque sus tendencias nacionalistas lo sugirieran, aceptar la idea de que con el tipo de clima, vegetación y carácter de la población de la costa caribeña colombiana y en general del trópico, se pudiera construir ciudadanos para la República. Cómo se podía integrar en las visiones de un personaje como Caldas, tanta diferencia, tanta diversidad, máxime cuando ni siquiera un hombre de ciencia como él las miraba de otra forma?

No es posible imaginar a un personaje como Caldas, con la mirada atónita ante las observaciones que tan fielmente describía pensando que pudieran sus interlocutores en Europa hablar bien de las poblaciones del Caribe Colombiano. Es difícil llegar a considerar la posición en la que se encontraba Caldas, tratando de pintar lo mejor posible a su país como un sitio civilizado, alejado de las barbaridades. Por tanto, había que construir un Otro con el que, al compararse, pudiera en últimas, sentirse mejor :

El amor, esta zona tórrida del corazón humano, no tiene esos furores, esas crueldades, ese carácter sanguinario y feroz del mulato de la costa. Aquí se ha puesto en equilibrio con el clima, aquí las perfidias se lloran, se cantan y toman el idioma sublime y patético de la poesía. Los halagos, las ternuras, los obsequios, las humillaciones, los sacrificios, son los que hacen los ataques. Los celos, tan terribles en otra parte y que más de una vez han empapado en sangre la base de los Andes, aquí han producido odas, canciones, lágrimas y desengaños. Pocas veces se ha honrado la belleza con la espada, con la carnicería y con la muerte. Las castas todas han cedido á la benigna influencia del clima, y el morador de nuestra cordillera se distingue del que está á sus pies por caracteres brillantes y decididos. (CALDAS, 1912:307).

Ese Otro lo encontró Caldas en la costa del Caribe Colombiano, que describe como una región no apta para el desarrollo de la especie humana, cuya su población tenía serios problemas de dispersión, falta de civilización y poca vergüenza, lo que la hacía objeto de múltiples preocupaciones por parte de los encargados de conservar el orden y la moral en las colonias.

Ahora bien, Caldas no fue el único que escribió de manera tan decidida sobre los comportamientos de los habitantes del Caribe Colombiano. De paso por Cartagena, Eliseo Reclus, notable geógrafo francés del siglo XIX, no solo decepcionado por la apariencia de la ciudad, anotó en su diario de viajero:

La primera escena de que fui testigo al poner en pie en las calles de Cartagena, redobló la tristeza que me había inspirado la vista de sus ruinosos edificios. En una plaza rodeada de casas ennegrecidas y de elevadas arcadas, dos hombres de cabellos lisos, de mirada feroz, tez de color indeciso, se habían agarrado de los jirones de sus ruanas, desenvainaron, vociferando, sus terribles machetes, y procuraban herirse con ellos. Á su alrededor se agitaba confusamente una multitud ebria y sucia; los unos gritaban con furor:Mátaloj, Mátaloj los otros hacían desviar los golpes de 
machete, deteniendo los brazos de los combatientes...Al fin se logró parar á los dos lidiadores, que seguidos de sus partidarios, se fueron, cada uno por su lado, á una tienda, donde unos y otros se entregaron, botella en mano, á todos los demonios del infierno. (RECLUS, 1992:53-54) personajes cartageneros habituados a la vida de bares y cantinas, al ser descrita en su diario de viaje, termina por mostrar la imagen de una ciudad donde al parecer sus habitantes estaban todos acostumbrados a vivir este tipo de situaciones en la más completa de las cotidianidades. Más aun, Reclus olvidaba una Francia, tal vez más habituada al alcohol y a la vida de bares y cantinas. No se puede aquí olvidar que Reclus igualmente procedía de una clase social, seguramente alejada del bullicio y la algarabía popular que tanto rechazaba en su descripción.

Por su parte, Augusto Le Moyne, viajero diplomático francés que visitó Colombia entre 1828 y 1839, escribió en su relato de viaje sobre los comportamientos de los bogas lo siguiente:

Una noche en que estalló una tormenta espantosa acompañada de una lluvia torrencial que obligó a los bogas a abandonar el puente, éstos se metieron a pesar de nuestras protestas, en el entrepuente, obligándonos a refugiarnos en un rincón. Uno de ellos tocó en la oscuridad una damajuana, y supuso que contendría aguardiente del que de vez en cuando les dábamos un poco, lo destapó calladito, bebió cuanto pudo y la pasó a los otros camaradas y uno y otro se entregaron a las mismas libaciones hasta que no quedó una sola gota del líquido. Esos desgraciados que al igual que todos sus semejantes tienen el gusto estragado tanto por el excesivo calor, como por el uso frecuente que hacen de los alcoholes más fuertes, no se dieron cuenta de que era vinagre y no aguardiente lo que habían bebido. (LEMOYNE, 1969:51).

Asimismo, Humboldt, también resaltaba dicha proclividad de los habitantes del Caribe Colombiano por el alcohol:

En el mes de mayo queríamos salir de Mompós. Todos los remeros estaban reunidos. Tan pronto vieron que queríamos subir al champán, recordaron que todavía no se habían bebido todo el sueldo que se les había adelantado. Ocho de ellos se largaron y nosotros pernoctamos en la ramada de ladrillo, a un cuarto de milla de la ciudad. (HUMBOLDT citado en NOGUERA, 1980:153).

Y a renglón seguido, apuntalando sus percepciones sobre los remeros (bogas) del Magdalena anotaba:

Cualquier trabajo que esté relacionado con una forma de vida errante y vagabunda encuentra hombres que lo prefieren más fácilmente y con menor resistencia. Por ejemplo, la vida de marinos, de soldados...Un remero gana en cuarenta días apenas doce pesos. Hay que pagarles por adelantado en Mompós y darles tres días después de la paga, con el pretexto de que tienen que mandarse hacer una camisa y un pantalón para el viaje. Estos días los emplean en beberse el dinero, y antes de que se hayan gastado todo, recoge uno sus bogas generalmente después de cuatro o siete días de espera...Uno es esclavo de sus remeros. (HUMBOLDT citado en NOGUERA, 1980:149).

Para Le Moyne, Reclus y Humboldt, el alcohol era un común denominador que envolvía cual hechizo infernal, los espíritus de los habitantes del Caribe Colombiano, no importando el lugar donde se encontraran, ni tampoco la actividad que desempeñaran. Esta relación con el alcohol entre los habitantes del Caribe Colombiano también aparece en los textos con los cuales se han narrado las gestas independentistas de Cartagena, como lo ha estudiado Múnera (1998, 157-176).

En el mismo sentido, Caldas y Le Moyne estaban convencidos que, de acuerdo con el determinismo geográfico, los habitantes del Caribe Colombiano eran afectados por el 
clima y de ahí devenía su carácter y comportamientos y de ahí también que ambos llegaran a las mismas deducciones. Así, refiriéndose a una de las situaciones en las que dos de los bogas habían desaparecido, utilizando uno de los mecanismos de resistencia más reprochados por los viajeros, como lo era escaparse y abandonarlos en medio del camino, Le Moyne escribió:

En esos dos días de detención forzosa, matamos la mayor parte del tiempo paseando por Pueblo Viejo; todos sus habitantes eran negros, mulatos o indios, únicas razas capaces de vivir en medio de los pantanos de la Ciénaga sin sentir los efectos de la graves enfermedades, que con un ambiente abrasador, húmedo y cargados de miasmas deletéreos no tardan en aquejar a los blancos que se aventuran por estos parajes. En efecto, los pocos europeos que vi en ellos después de haberse aclimatado, poco a poco tenían el rostro macilento, amarillo y parecían como reídos por una fiebre lenta. (LEMOYNE, 1969:42-43).

No había duda:hasta a los blancos europeos, el clima les podía afectar, deformándolos (y asemejándolos) a los nativos del Caribe Colombiano. Esta afirmación no era una cuestión baladí, pues ponía en tela de juicio la reconocida idea de la existencia de "razas superiores", pues una vez estas cayeran en territorios tropicales, pronto se vería su decadencia; me refiero al problema del determinismo geográfico, asunto en el que no importando la "raza", todos se verían indiscutiblemente afectados.

Este cúmulo de percepciones despectivas por demás sugerentes sobre los habitantes de la costa caribe colombiana, no era desconocido por los gobernadores, ni provinciales, como tampoco por el clero y las clases pudientes. Más de una vez la intervención por parte de las autoridades encargadas del control no se hizo esperar. La disposición con arreglo a estas desavenencias se buscaron a través de la fundación de pueblos, lo que permitiría reunir en puntos definidos, la población díscola y desordenada de la provincia.

Por su parte, las autoridades eclesiales, encargadas del buen nombre, la moral y las buenas costumbres, hicieron también sus propios esfuerzos, aunque no tan frecuentemente como se podría esperar. Una de las mayores preocupaciones la ofrecían las poblaciones de la "inferior clase", debido a la notable relación de las costumbres y al incumplimiento de los deberes cristianos, por lo cual se dispuso asimismo, la fundación de parroquias en aquellos lugares recién fundados o agregados. Dos de los intentos más conocidos por parte de la iglesia con tal de reestablecer el orden mencionado, las llevaron a cabo un par de personajes de forma bastante dificultosa, de hecho uno de ellos, Don Manuel de Sosa Betancourt, natural de Las Palmas (Islas Canarias), quien emprendió una gira hacia el año de 1784, no logró prolongar su vida mucho tiempo después de concluir su gira por la región. Su desánimo al terminar su periplo por toda la provincia fue tal, que incluso pidió ser relevado de su cargo y trasladado de obispado. En su informe de gestiones plasmó una de las frustraciones más interesantes que se pueden obtener de la época:

El día 15 del p.p de febrero regresé del partido y del río del Sinú, dejando con esto terminada la visita de todo el obispado, aunque tan molestado de accidentes, siendo los más penosos los acaecidos en esta última salida, a causa de que los ardientes climas de aquel partido y plagas abundantes de mosquitos, garrapatas y otras sabandijas me acometieron de suerte; que reducidas las piernas a llagas, no me las visto, desde que entró el mes de diciembre (...)

(...) encarecidamente le suplico tenga compasión de mí, y me saque de este purgatorio, aunque mejor diría, infierno, según lo que se experimenta. (DE SOSA BETANCOURT citado en MARTINEZ, 1986). 
segunda visita a toda la región fue emprendida por otro sacerdote cerca de veinte años más tarde, por quien fuera también obispo de Cartagena:José Fernández Díaz de la Madrid. Recién posesionado, llevó a cabo una visita por aquellos lugares que comprendían la jurisdicción a su cargo. Este sacerdote, de voluntad fuerte y de una personalidad arrolladora que hacía temblar a los demás sacerdotes de su obispado, era a su vez, dueño de una pluma y de una memoria envidiable, con la cual plasmó en sus informes lo que observó entre su grey. Sólo el título de su informe:La universal relajación y corrupción de las costumbres de los fieles de la Provincia de Cartagena, resulta por demás interesante y deja ver lo implacable de sus concepciones cristianas con respecto a la moral y las buenas costumbres de los habitantes de la región caribe colombiana. De este informe, se retomaran algunas citas referentes a sus concepciones acerca de las festividades de los negros, mulatos y zambos en el interior de la provincia, así como sus observaciones sobre la provincia misma.

En el año 1781, emprendió nuestro obispo Díaz de la Madrid su agitado paseo por las parroquias, dicho sea de paso, lo suficientemente distantes de la capital, como para que el control eclesial no funcionara como se esperaba. Díaz de la Madrid se encontró, con la región sumida en el total abandono espiritual y según sus propias palabras, en el más absoluto olvido de uno de los alimentos más necesarios en la vida de sus "ovejas", "el pasto para el alma". De esta forma, en uno de los apartes de su quejoso informe escribió:

Fluctuando en dos contrarios extremos de placer y de pena, prevalecía ésta y se anegaba mi pecho en un proceloso mar de tribulaciones al advertir y experimentar la universal relajación y corrupción de las costumbres de los fieles; la infidelidad, miseria y desdicha de muchos vecindarios, la falta de pasto espiritual por carecer de párrocos...y sobre todo el abandono y olvido de las obligaciones de los cristianos y el deplorable estado de las iglesias...no faltaron (sacerdotes) quienes no tuviesen siquiera un pan que ofrecerme para el sustento por el justo título de procuración, siéndome forzoso llevarlos a comer a mi mesa. Bien que otros...por suponer indebida esa contribución afectando pobreza, o ejecutaron lo propio o me prepararon tan ruines viandas que apenas las apreciaría un mendigo a quien se diesen por pura caridad. (FERNANDEZ citado en BELL LEMUS, 1991:154).

De este modo, a la desidia, al alcoholismo y a la falta de moral de los habitantes del Caribe Colombiano, ya señalada por otros viajeros, había que sumarle su poco apego por el cumplimiento de los preceptos religiosos. La sorpresa del obispo fue mayúscula cuando intentaba hacer que las gentes asistieran a misa, pues los mecanismos de resistencia iniciados por los negros, mulatos y zambos, incluían no asistir a las iglesias:

Es muy común la ignorancia de la doctrina cristiana por no querer concurrir los libres a que se les instruya en ella y rehúsan mandar a sus hijos y dependientes a tan santo sacrificio diciendo que no son indios, como que sólo éstos tuvieran obligación de aprenderla, no habiendo otro modo de compelerlos (porque ya son ociosas cualesquiera exhortaciones y requerimientos) ya que el que por su majestad se comunique orden con severos apercibimientos a las Justicias Reales a fin de que presten, sus auxilios a los párrocos. (...).(FERNANDEZ citado en BELL LEMUS, 1991:156).

Asimismo, en las noches llegó a toparse con las manifestaciones festivas de los habitantes de los campos:

Igual remedio se necesita con los más estrechos encargos a las Justicias Reales para que celen y eviten en las vísperas de las fiestas los bailes, que vulgarmente llaman Bundes, a lo menos desde las nueve de la noche en adelante para que se consiga que las gentes que asisten a ellos no dejen de oír misa en el siguiente día, como frecuentemente acontece, no sólo en los sitios y lugares, sino también en las villas y 
ciudades, sin exceptuar esta que es la capital de la provincia. (FERNANDEZ citado en BELL LEMUS, 1991:156).

Y agregaba, no sin cierta amargura:

Los que concurren son indios, mestizos, mulatos, negros y zambos, y otras gentes de la inferior clase:todos se congregan de montón sin orden, ni separación de sexos, mezclados los hombres con las mujeres, unos tocan, otros bailan y todos cantan versos lascivos, haciendo indecentes movimientos con sus cuerpos. En los intermedios no cesan de tomar aguardiente y otras bebidas fuertes que llaman guarapo y chicha y duran estas funciones hasta cerca del amanecer. Ya se dejan considerar las proporciones que hacen para el pecado la oscuridad de la noche, la continuación de las bebidas, lo licencioso del paraje, la mixturación de los sexos y la agitación de los cuerpos, de todo lo cual han de resultar las fatalísimas consecuencias que pueden inferirse y de aquí dimana que embriagados los unos, entorpecidos los otros y cansados y rendidos del sueño todos, o no vayan a misa en la mañana siguiente (que es lo más ordinario) o no puedan oírla con la competente devoción. Ningún medio de cuántos me he valido ha sido bastante a contener estos daños. (FERNANDEZ citado en BELL LEMUS, 1991:157).

Lo que encontró Díaz de la Madrid fueron poblaciones cuyos habitantes se habían acostumbrado durante muchos años a vivir una realidad alejada de los controles estatales, dispersa, sin autoridad visible, sin normas, y excluida de la estratificada sociedad colonial de finales del siglo XVIII; sociedad donde sólo cabía un orden donde los espacios no se transgredían para precisamente tratar de preservarla (Balandier, 1993). El problema aquí estribaba en que frente a un estado colonial débil y frente a una iglesia casi ausente; tal como lo mostraba el obispo en su informe, no resultaba nada extraño que a Díaz de la Madrid la eliminación de las fronteras entre esos espacios donde el género y la raza se entrelazaban, le resultase bastante sintomático y deleznable, de ahí su queja y reclamo.

41 Pero, además, al igual que otros extranjeros, que visitaron la zona también se chocó con una realidad social, que quizás no era necesariamente distinta a la que se vivía en las ciudades europeas, tal y como se desprende de las impresiones dejadas por ellos en sus escritos. En otras palabras, es bastante probable que los viajeros y funcionarios que visitaron y experimentaron diversas situaciones en la región, también las hubiesen observado en otras latitudes, pero no necesariamente las evidenciaron, porque en últimas, era sobre los habitantes del Caribe Colombiano en quienes recaían en este caso dichas percepciones de rechazo ante sus comportamientos.

En ese mismo sentido, José Celestino Mutis, al visitar las iglesias en Cartagena encontró que:

La gente que acude en estas...misas es, por lo regular la más inferior. Su modo de entrar, perseverar y salir de la iglesia, es muy conforme a la educación de esta gente, cuyos defectos están en la vista. Causa bastante novedad a cualquier hombre cristiano, ver entrar en un templo, para asistir a tan alto sacrificio, un gran número de mulatas y negras, entre las cuales algunas no tienen otros adornos para el día de fiesta que los que gastan para los demás días. He visto entrar a muchas sin otro adorno y vestido que más que las enaguas y una camisa mal puesta, por cuyo motivo llevaba descubiertos gran parte de sus pechos, espalda y hombros, descalza y sin la gorreta que acostumbran a llevar en la cabeza otras mulatas y negras. Mientras asisten al templo dan pocas señales de devoción, y confirman su tibieza en el modo de salir de la iglesia. (MUTIS, 1991:110).

Así, la ciudad, pero sobre todo el campo, estaba plagado de gentes cuya moral y costumbres no eran del agrado de los más de los viajeros. Sin embargo, no dejan de ser contradictorias las observaciones que personajes como Caldas y Mutis, e incluso hasta 
el mismo Humboldt, quienes a pesar de ser científicos, no ofrecían una postura un tanto más distanciada de las cuestiones religiosas y morales. Se trataba aquí de posturas en las que al parecer la ciencia y la religión parecían estar tomadas de la mano, aunque no lo estuvieran.

\section{Las "gentes de la inferior clase" en la visión de los viajeros}

43 En adición a la cuestión del determinismo geográfico, constante en todas las descripciones sobre la región, otro aspecto a destacar en la producción escrita de los viajeros, es la visión que estos tenían hacia quienes consideraban "gentes de la inferior clase”. A quienes se referían bajo este término ? No basta aquí con la sola alusión al concepto de clase, pues no solo median cuestiones de índole económica. Más bien habría que aclarar que, en adición a las cuestiones económicas, hay que añadirle cuestiones étnicas. En cualquier caso, viajar por el caribe colombiano suponía inexorablemente compartir espacio físico con estas "gentes de la inferior clase", con todo lo que ello implica en términos de socialización y relación con el Otro. Por otro lado, el término "gentes de la inferior clase" fue una manera de agrupar una porción de los habitantes que no encajaban en la división social establecida de república de indios y república de blancos y que por tanto, se convertía en un verdadero dolor de cabeza para las autoridades coloniales (Cunin, 2003).

A su llegada a Cartagena por vía marítima, los visitantes extranjeros debían emprender el largo viaje hacia la capital de la colonia o bien de la república en su momento, con propósitos distintos, en función de si se trataba de un viajero, un eclesiástico o un funcionario. La travesía, que demoraba cerca de dos meses, debía hacerse en unas canoas conocidas como Champanes, las cuales:

...tiene(n) 23.5 metros de largo y 2 metros de ancho en el centro. El piso es... rectangular, una forma incómoda, pero ciertamente necesaria para la estabilidad. El centro del champán...es curvado, cubierto con un elevado toldo de seis pies de altura, de palmera tupida. En el extremo posterior libre se hace fuego, y allí, mudos y con expresión de misteriosa importancia, están el timonel y delante de él, el copiloto. En la parte delantera.., trabajan seis hombres, arriba sobre el toldo cuatro, todos, todos a la palanca, con varas bifurcadas en el extremo, largas de doce a dieciocho pies. La forma en que estos bogas trabajan es muy rítmica. Mientras que una mitad (de los bogas), avanza hacia el toldo con la palanca apoyada contra el pecho, los otros...caminan en dirección opuesta con los brazos levantados. Cuando una mitad alcanza este extremo, la otra llega al otro. (...) No existe indiscutiblemente ningún trabajo de mayor esfuerzo muscular que el de los remeros del Magdalena. (PEÑAS GALINDO, 1991).

Estas eran embarcaciones de madera donde podían viajar cerca de 20 personas, entre tripulación y pasajeros, y eran construidas por los mismos habitantes de las zonas ribereñas para navegar entre una población y otra. Ahora bien, para efectuar la larga y dispendiosa travesía por el río, se contrataban los servicios de los bogas, quienes eran dirigidos por un patrón, quien era el dueño del Champán y este a su vez, reclutaba a los demás compañeros de faena.

Dado que hasta mediados del siglo XIX no se inició la navegación a vapor por el río Magdalena, durante los siglos precedentes, la labor de llevar a los viajeros de camino hacia la capital del virreinato la efectuaban los bogas (Solano, 2003). Sobre las 
experiencias de compartir el viaje obligatoriamente (aunque a regañadientes), con los bogas, se puede afirmar que ninguno de los viajeros dejaron de mencionar las peculiaridades del encuentro y vivencias con estos habitantes de las zonas cercanas al río. Así, por ejemplo, una de las descripciones más interesantes sobre el trabajo de los bogas, se puede encontrar en los escritos de Alexander Von Humboldt, quien escribió al respecto:

La forma en que estos bogas trabajan es muy rítmica. Mientras que una mitad (tres en la parte de abajo, por ejemplo), avanza hacia el toldo con la palanca apoyada contra el pecho, los otros tres caminan hacia abajo con los brazos levantados... Cuando una mitad alcanza el extremo, la otra llega a otro...La palanca tiene de doce a quince pies de largo y en extremo inferior tiene amarrada una horqueta, de ocho a nueve pies de largo. Puesto que los bogas apoyan la palanca contra el pecho arriba de las tetillas, todos tienen allí una terrible callosidad...Por suerte los hombres tienen poca disposición al cáncer de pecho. (HUMBOLDT citado en BELL LEMUS, 1980:147).

Humboldt dedicó extensos apartados de su diario de viaje por el Magdalena a tratar de explicar la manera como estos personajes trabajaban, a los cuales, dicho sea de paso, admiraba y rechazaba a la vez:

Es muy pintoresco cuando estas figuras bronceadas de fuerza atlética, avanzan poderosamente apoyados en la palanca. La forma como se les hincha cada vez la vena yugular, cómo chorrena sudor diariamente en un clima cálido ardiente, en la cuenca de un río en el que casi nunca sopla un airecillo bienhechor que mueva las hojas. A pesar de lo admirable de esta demostración de fuerza humana, yo hubiera deseado admirarla por menos tiempo. (HUMBOLDT citado en BELL LEMUS, 1980:147).

Esa sensación de desconcierto y repudio, probablemente se pueda entender por su irrenunciable vocación de científico por un lado, pero también, por el otro, no hay que olvidar su procedencia europea. De esta forma, Humboldt se asombra y siente repulsa por los sujetos que describe:

No es que estos hombres despertaran compasión, pues aunque mal pagados..., son hombres libres, a las veces muy altivos, indómitos y alegres. Su eterna alegría, su buena nutrición...todo esto disminuye el sentimiento de compasión. Pero lo más enojoso es la bárbara, lujuriosa, ululante y rabiosa gritería, a veces lastimera, a veces jubilosa; otras veces con expresiones blasfemantes, por medio de las cuales estos hombres buscan desahogar el esfuerzo muscular. (HUMBOLDT citado en BELL LEMUS, 1980:147-148).

Humboldt reconoce que los esfuerzos físicos a los que están expuestos los bogas son admirables, y por momento se detiene en su narración para justificar tal sensación, aunque termina enojado por la conducta que dichos esfuerzos producen. Esta doble sensación de entusiasmo y censura también la experimentaron otros viajeros. Charles Stuart Cochrane, un capitán de navío británico, quien visitó Colombia entre 1823 y 1824, describió el mismo tipo de experiencias de la siguiente forma:

Un poco antes de llegar al Magdalena concentré mi atención en unos gritos que provenían de los bogas que formaban la tripulación de un largo champán; en el sitio donde nos hallábamos, el caño era apenas lo suficientemente ancho para las dos embarcaciones. Al pasar junto a ellos alcanzamos a apreciar las ridículas gesticulaciones que hacían en su laboriosa tarea. Ellos impulsaban la embarcación con unos remos largos extendiendo y recogiendo sus brazos hasta la altura del pecho y produciendo una serie de sonidos acompasados. (COCHRANE, 1994:44).

50 John Potter Hamilton, un coronel, diplomático y viajero inglés, designado jefe de la comisión diplomática enviada por Inglaterra para establecer relaciones formales con la 
recién creada Republica de la Gran Colombia en 1823; dejo en sus memorias, la misma sensación dual entre la admiración y el rechazo. Veía la labor de los bogas así:

A los bogas, a causa de los esfuerzos y constante caminar sobre las cubiertas calientes, se les hinchan las piernas y con frecuencia vimos en las aldeas a jóvenes inválidos por esta clase de trabajo...Como este es el caso, al viajero no le queda otra alternativa que acortar la penitencia lo más rápidamente posible; para tal fin, recomiendo encarecidamente llevar consigo dos o tres barrilitos de ron y dos o trescientos cigarros y darles a los bogas siempre que trabajen bien, dos o tres cigarros y un vaso de ron por la mañana y otro por la noche. Estos pobres infelices verdaderamente lo merecen, porque impeler durante tantas horas bajo un sol abrasador es un trabajo extraordinariamente pesado y sin duda mataría a cualquier europeo en pocos días. (POTTER, 1993:63-64).

Potter Hamilton creía firmemente en los poderes paliativos que ejercían el cigarrillo y el alcohol en la dificultosa y extenuante tarea de los bogas y por ello recomendaba traerlos a estos viajes. De hecho, al reconocer la admirable y sobrehumana (sobre todo frente a los europeos a quienes veía débiles en comparación), labor de los bogas, recomendaba acortar la penitencia, sencillamente termina no soportando semejante cuadro, a pesar del repudio que dichos personajes le generaban.

Por su parte, Augusto Le Moyne al respecto de este tipo de situaciones en las que una doble emoción cuestiona el criterio con el cual se evalúan los comportamientos y conductas de los habitantes del Caribe Colombiano, sostenía en su relato de viaje que:

Los bateleros que teníamos a bordo eran trece con el patrón que a la vez hacía de piloto; pertenecían a esa clase de gentes que en el país se llaman bogas y que se reclutan entre los negros, los mulatos y los indios de sangre mezclada. Antes de empezar el trabajo penosísimo a que se iban a entregar, nuestros hombres, como suelen hacerlo en casos semejantes en cuanto no están a la vista de las ciudades, se despojaron de todas las prendas de vestir no conservando más que un calzoncillo corto, unos, y otros unos trapos alrededor de la cintura...con esta vestimenta más o menos paradisíaca, casi todos ellos hombres jóvenes, se distinguían por sus formas atléticas y por su aspecto imponente, debido a ese aire arrogante y a las hermosas proporciones de sus miembros. (LE MOYNE, 1969:36).

53 Le Moyne también reconocía el esfuerzo físico que el trabajo de batelero requiere y aún más, al observar la contextura física de estos sujetos, no ocultaba su encanto, más bien lo exaltaba, aunque se nota la dualidad en su percepción como se ha visto en otros casos de viajeros ya citados. No obstante, si bien por una parte Le Moyne admiraba la belleza atlética de los bogas, nada lo hacía perder de perspectiva, la coherencia de su discurso en el sentido de identificarlos claramente como otros, los cuales no dudaba en discriminar abiertamente:

Al contemplarlos con los torsos inclinados hasta la altura de las rodillas se hubieran podido tomar por bestias de carga que tirasen de la soga para arrastrar pesados fardos. No hay que pensar que después de hecho el primer esfuerzo el trabajo de esos desgraciados se aminora ya que solo por el esfuerzo continuado y el continuo avanzar de ellos sobre el puente es como se puede contener y hacer avanzar la embarcación. Hasta cierto punto se podría concebir que la profesión de boga la escogiesen únicamente cierta clase de gentes rudas que no tuviesen más que aptitudes para ser cargadores (...). (LE MOYNE, 1969:36-37).

54 Ahora bien, gracias a la presencia de una vía natural que recorre el país de sur a norte, el río Magdalena, los habitantes de la región desde tiempos inmemoriales hacían recorridos intercambiando, a manera de trueques, alimentos y otros objetos para su 
subsistencia (Solano, 1998; Nichols, 1973). De hecho, el modelo de vida arrochelada, se daba gracias a ello.

Lo interesante de este sistema de comunicación, demasiado lento para el ritmo de vida que traían consigo los visitantes europeos, es que era conocido y controlado casualmente por esas "gentes de la inferior clase", que como se ha visto anteriormente, eran denominadas gentes de todos los colores. El hecho es que el modelo de vida de estos habitantes chocaba con el ritmo del extranjero. Por un lado, el de los viajeros era el modelo de vida de una sociedad europea, donde por lo menos Inglaterra era ya industrializada, y otros países como Francia y Alemania no estaban muy lejos de seguir el mismo proceso; mientras, por el otro, el estilo de vida de los bogas y demás habitantes del Caribe Colombiano, era propio de sociedades preindustriales, donde todavía el tiempo no tenía un uso tan racional como en Europa y donde las formas y usos sociales aun dejaban mucho que desear para los visitantes extranjeros (Thompson, 1979).

Para la gran mayoría de los habitantes de las poblaciones de la región, la presencia de personas ajenas a su cotidianidad, era un verdadero suceso, porque casi ningún desconocido se acercaba por aquellos parajes, a menos que fuera de camino hacia la capital. Para la muestra un botón, como se dice en el lenguaje popular, y aunque se escapa a la temporalidad del presente estudio, el ejemplo puede servir para ilustrar un poco lo que se está afirmando.

57 A finales del siglo XIX, Ernts Rothlisberger, un profesor universitario de origen suizo quien fue contratado por el gobierno colombiano para fungir como profesor de historia universal y filosofía en la Universidad Nacional de Colombia en 1881, de paso por la costa del Caribe Colombiano narró así sus experiencias al encontrarse con los habitantes de la región:

Inmediatamente de sonar la pitada del vapor, salen del bosque los más variados tipos de gentes, y corren a lo largo de la ribera, que ahora se ha hecho más alta, o se acercan con ligeras canoas. Llegaban las negras, las mulatas e indias con un andar rápido, no exento de gracia y delicadeza, y echados hacia atrás la cabeza y el cuerpo. Las madres llevan a sus pequeños a horcajadas sobre las caderas. Estas gentes ofrecen a los del barco diferentes cosas de comer, y, acurrucados en el suelo, cambian con ellos algunas palabras, sin impertinencia ni descortesía alguna. Pero cuando algún forastero se les dirige en mala forma, saben replicar con doble crudeza; luego desaparecen detrás de uno de aquellos magníficos árboles, y tengo la sensación de que se retiraran a un mundo desconocido. (ROTHLISBERGER, 1993:57.

Del texto podemos percibir una actitud respetuosa por parte de los habitantes de las riberas del Magdalena hacia el visitante extranjero y pero sobre todo, a diferencia de otros viajeros que le precedieron, mostraba cierta simpatía por los habitantes de la región, en especial por sus mujeres, a quienes consideraba por demás simpáticas y graciosas. Sus percepciones muestran hasta qué punto no todo lo que escribieron era homogéneo, pues había contradicciones entre uno y otro. Por otro lado sobre él se depositaba cierto poder que ejercía entre las poblaciones visitadas, pues el hecho de ser blanco y de portar cartas de presentación otorgadas en Cartagena, le concedía el servicio irrestricto de los representantes del gobierno en la costa. Simultáneamente, pero no de manera expresa como ocurría con el respeto que generaba el extranjero, los encargados de navegar los champanes, es decir, los negros, mulatos y zambos, ejercían un poder, pues sólo ellos tenían la experiencia acumulada de muchos años en las faenas de la navegación subiendo por el río hasta la capital. Estos dos poderes, estaban en 
constante pugna, pues cada cual en un espacio propicio lo ejercía (Scott, 1985). A este respecto, Augusto Le Moyne anoto en sus descripciones una queja sobre el comportamiento inmoral y poco pudoroso de los bogas a los cuales acusaba no $\sin$ expresar su impotencia:

A estas molestias hay que añadir que vivir la mayor parte del día en un espacio tan reducido en medio de esas gentes, que en su desconocimiento de lo que nosotros llamamos el pudor no se recatan en lo más mínimo para proferir los dichos más soeces y satisfacer las necesidades físicas en presencia y hasta al lado de uno, sin que las observaciones y las amenazas les hagan modificar sus costumbres. (LE MOYNE, 1969:38).

Probablemente Le Moyne se refería a la costumbre de orinar parado sobre la cubierta del champán, cosa que no se sabe dónde más podrían los bogas hacerlo, dado que estaban navegando por el río. Se podría decir, que el viajero dependía de la pericia del boga, pues aunque es el viajero quien decidía que hacer, todo estaba supeditado al ánimo del boga. El mismo Le Moyne, al efectuar su travesía junto a los bogas y quejarse por el comportamiento de dichos personajes escribió:

$\mathrm{Al}$ aproximarnos a Regidor empezamos a divisar las montañas de la tierra de Ocaña. Avanzábamos, tanto más despacio, cuanto que cada vez que nos acercábamos a un poblado los bogas a pesar de nuestras protestas nos hacían perder horas enteras deteniéndose en ellos para beber y sobre todo para alzarse, como buenos merodeadores, con naranjas y racimos de plátanos, sin soltar un céntimo, rapiñas de las que parecíamos ser cómplices y que muchas veces originaron disputas con los dueños de los huertos allanados. (LE MOYNE, 1969:38).

El uso del tiempo, tan importante para el extranjero, no tenía la misma importancia para el boga:Debido a los días festivos que hubo durante esta semana, nos tocó esperar hasta el sábado 29 ya que era imposible conseguir un barquero (Cochrane, 1994:46), y aún a pesar de ser un subalterno frente al dominio del viajero, el boga solía salirse con la suya:realmente fuimos burlados:los bogas no se presentaron a la hora de salida acordada (Cochrane, 1994:49). El tiempo era -y en cierta medida, aun lo sigue siendo, en el caribe colombiano, una representación colectiva ligada directamente a las manifestaciones culturales de la región (Berian, 1991). Por tanto, y aunque en las descripciones se escribiera lo contrario, no necesariamente para los habitantes de la costa caribeña colombiana, el tiempo dejaba de tener importancia. La tenía, pero no en la misma relación que le adjudicaban los viajeros:

Le pedimos información al patrón sobre las diferentes paradas que deberíamos hacer para llegar a Honda en 15 días como habíamos acordado. Cuando él empezó a enumerarlas las escribimos y encontramos que, a cambio de las 15 que inicialmente se habían programado, ahora había 12 más; como no lo pudimos persuadir de disminuir el tiempo, y además, nos pareció un perfecto bribón, que probablemente nos abandonaría puesto que llevaba algunos artículos para la venta, decidimos no continuar adelante con él. (COCHRANE, 1996:63).

En otras palabras, el tiempo es una representación cultural aprendida. Cada individuo de la comunidad incorpora, basado en la experiencia cotidiana, unos usos característicos del medio donde se desenvuelve. De esta manera, el tiempo, tan caro para las exigencias del viajero, no tenía el mismo significado para el boga y de paso para los demás habitantes del Caribe Colombiano. Tal vez desde los momentos mismos en que se inició el proceso esclavista, el negro, así como algunos pocos indígenas que sobrevivían a las enfermedades y al maltrato de los españoles, habían aprendido a 
hacer un uso del tiempo sin usufructo, es decir, de ocio, cuando no se estaba trabajando arduamente en las labores impuestas por quienes los dominaban.

Para algunos científicos sociales, tales como Norbert Elías, el tiempo en su medida racional, produce "civilización", es decir, el grado de civilización de una sociedad determinada, está directamente relacionado con el uso racional que esta sociedad haga del tiempo (Elías, 1987; Lippincott, Eco, Gombrich, 2000). Bajo este parámetro de construcción moderna, las sociedades modernas han construido el paradigma de su propia auto representación. En el siglo XIX, estas concepciones estaban todavía más arraigadas entre los europeos. De hecho, con ellas fueron observados y a través de tales ópticas fueron descritos.

El tiempo de trabajo, completamente racional del extranjero, era un momento de máxima producción. El tiempo era oro, y lo sigue siendo dentro de las sociedades capitalistas. Sobre ello no cabía la menor duda y en eso no podía haber espacios de mediación. Por su parte, el habitante de las zonas ribereñas del Magdalena, no tenía ninguna prisa en su trabajo. Conocía mejor que nadie las vicisitudes del trayecto y se enfrentaba a ellas con la más absoluta tranquilidad, aun en contra del desgano de su huésped.

Esta contrariedad en la pérdida del tiempo por parte de los bogas y demás habitantes del caribe colombiano que los viajeros rechazan y de paso denuncian, solo es posible entenderla si, como dice Todorov, el interlocutor se ubica del lado del boga, para comprender que frente a un clima ardiente, un trayecto de varias semanas remando e impulsando una embarcación a todas luces pesada y en contra de la corriente del río, es decir, río arriba; nada extraño resulta que el boga adoptase sus comportamientos frente a dicha realidad por demás extenuante (Todorov, 1982:195).

El ocio, momento de tranquilidad para el extranjero, era el resultado de un largo momento de trabajo:"Después del trabajo viene un merecido descanso", esa era la norma. No obstante, nada más contrario en el caso de los bogas y demás habitantes del caribe colombiano:el trabajo sólo es posible llevarlo a cabo con cierto disfrute, con otras palabras, con instantes de ocio:mientras se trabaja se canta, mientras se trabaja se pesca, mientras se trabaja se bebe, unos comportamientos que sin duda resultaban completamente contradictorios a los ojos de quien tiene ya parámetros establecidos sobre cómo, dónde y cuándo se deben llevar a cabo ciertas acciones, pero sobre todo, que contrariedad, cuando se mezcla una cosa con la otra.

La concepción judeo-cristiana de que el trabajo es un castigo por los pecados cometidos, tiene sentido dentro de la concepción cultural del habitante caribeño. No de otra manera es posible entender que el boga trabajara únicamente lo necesario para subsistir. No había otra dimensión. Los habitantes de la región se adaptaron culturalmente a unas formas y costumbres que diferían en el pasado y que aún hoy difieren mucho al de las demás regiones del país, y en eso han jugado un papel preponderante cuestiones de tipo social, históricas y económicas.

El boga trabajaba arduamente durante la semana, y al fin de la misma disfrutaba parrandeando:"El hombre que trabaja y bebe, déjenlo gozar la vida!", reza un vallenato muy popular de la costa Caribeña colombiana, como justificando este estilo de vida, ligado a las concepciones culturales antes mencionadas, pero también sugiere una visión del trabajo ligado al castigo. Trabajar es sufrir. Ahora bien, existen obviamente otras posturas religiosas, entre ellas el protestantismo, que considera que el trabajo dignifica 
al hombre; que más allá de ser un castigo de origen divino, el ser humano masculino se hace hombre al trabajar (Weber, 1978).

El último texto a considerar en este estudio data de principios de 1824, cuando aún las cenizas que quedaron luego de las gestas independentistas estaban aún humeantes, llegó a Cartagena, de camino hacia Bogotá, el coronel Gaspard Théodore Mollien, diplomático y explorador de origen francés; hombre de temperamento fuerte y que había estado en otros lugares del mundo, haciendo grandes expediciones, sobre todo al África. Este personaje es tal vez una de las representaciones más extremas del eurocentrismo y del etnocentrismo que visitaron el Caribe Colombiano. Pero aún más fuerte es su claro desprecio por las regiones cálidas y por sus habitantes, en especial, por los negros. En sus primeras impresiones sobre Cartagena este personaje escribió:

Cartagena presenta el aspecto lúgubre de un claustro:largas galerías, columnas bajas y toscas, calles estrechas y sombrías en razón al saliente de los tejados que sustraen la mitad de la luz; la mayor parte de las habitaciones están sucias, llenas de humo, tienen un aspecto mísero, y cobijan seres que están más sucios, más negros y más miserables aún:Tal es el aspecto que ofrece a primera vista esta ciudad, bautizada con el nombre de la rival de Roma.(...) Su población, que es de 18.000 habitantes, se compone casi toda ella de hombres de color...Trabajan muy bien la concha, son excelentes joyeros, buenos carpinteros, magníficos zapateros, sastres regulares, mediocres ebanistas.....albañiles carentes de ideas de proporción, malos pintores, pero eso sí son aficionadísimos a la música. (MOLLIEN, 1944:15).

Mollien ignoraba que la razón por la que la arquitectura de la ciudad buscaba robarle luz al día tenía un sentido apenas lógico:se quería hacer que la cercanía entre los tejados de un lado de la calle y los del frente, les proporcionara sombra a los portales de las casas y de paso a los transeúntes, quienes se cobijarían del inclemente sol.

Llama también la atención en este personaje, que si bien es cierto rechazaba el orden de cosas (urbanismo), que encontró a su paso por la ciudad en 1824, orden que dicho sea de paso, no comprendía y que estaba muy lejos de querer comprender, también es cierto que algunas labores le generaron asombro y consideración, especialmente viniendo de él. Se puede notar en sus palabras, la fluctuación entre la aceptación, la sorpresa y el rechazo hacia las labores artesanales que comúnmente realizaban los negros y demás libres de la ciudad.

71 De la misma forma, Mollien al referirse a los habitantes de Cartagena, mostraba su descontento no sólo por lo que en su opinión era todo un desorden, sino también, por los comportamientos, que muy a su disgusto, los negros mostraban pese a su presencia:

Los peligros del mar...han desarrollado en esa gente de color un orgullo que a veces resulta molesto. Su vehemencia y su petulancia contrastan con la indolencia y con el buen carácter de los hombres que llaman blancos, de modo que, a pesar de su pereza, parecen activos y laboriosos. Son también los que se dedican al contrabando; y lo hacen con tan poco recato, que constituye una afrenta para los funcionarios encargados de reprimir ese desorden. (MOLLIEN, 1944:17).

Mollien creía que el negro debía adoptar una postura humilde frente a él. Esa se suponía que debía ser la escena, pero no lo era. El negro, muy a su pesar, adoptaba una posición desafiante, de abierto rechazo frente a la opresión que dictaba el orden social imperante y que dicho sea de paso, a Mollien le interesaba conservar. Mollien se encontró con una sociedad donde las relaciones de poder parecían tener dos facetas:Por una parte la clase pudiente o de elite, que entre otras cosas estaba compuesta por blancos, y por otra parte la de los 'negros petulantes' que subvertían con sus actitudes el orden social, aspecto que incomodaba enormemente al autor, pero que sobre todo, le 
producía una profunda perturbación, pues, como se ha dicho en líneas anteriores, a Mollien le interesaba conservar las estructuras socio raciales a las que seguramente estaba acostumbrado y dentro de las cuales el indudablemente ocupaba un rol ventajoso frente a los negros. Sin embargo, a pesar de lo interesado de su discurso racial, lo cierto es que Mollien tuvo que reconocer que las distancias entre negros y blancos parecían, aún en medio del rechazo que los primeros le generaban por su color, no estar tan alejadas. Con todo ello, un análisis global del texto revela que el principal interés del autor consistió en elaborar un discurso que mantuviese reales distancias de poder, situándose del lado de los grupos dominantes y salpicando su texto de ataques peyorativos respecto a los negros relativos a su capacidad de entendimiento. No en vano, en algún momento de sus reflexiones escribió refiriéndose a la provincia de Cartagena:

En los países españoles todos rezan, juntos, a Dios, cualquiera que sea el color de la piel, y el pueblo no tardaría en sublevarse si las autoridades pusieran a la puerta de las iglesias un aviso que dijera:today instruction for the men of colour. (Hoy, doctrina para las personas de color). (MOLLIEN, 1944:17).

Probablemente, tal aviso de "today instruction for the men of colour" le parecía más lógico y socialmente aceptable, que ver a las negras y mulatas con sus escotes prolongados, como lo evidenciaron en sus descripciones Mutis, Humboldt y otros viajeros más en sus descripciones.

Acercarse a las memorias que éste y otros extranjeros que visitaron el Caribe colombiano en el siglo XVIII y principios del XIX escribieron, implica tratar de entender que la situación con la que se encontraron estos viajeros, les hacía sufrir un serio choque cultural. De hecho, tener que depender durante más de un mes de los negros, mulatos y zambos que los conducían por regiones inhóspitas y deshabitadas, significaba todo un drama:el boga era alcohólico, era burdo en la manera de tratar y de comer y era inmoral en la manera como se vestía. Paralelo a ello, les hacía tardar más tiempo del necesario en una región donde los mosquitos hacían mella en la poca paciencia, que ya de por sí, menguaban con sus comportamientos las gentes de las poblaciones visitadas. Precisamente, quedar bajo el poder de estos sujetos debió ser una situación sumamente incomoda y humillante, digna de ser reseñada en sus memorias de viaje.

Mollien no fue la excepción al describir y denunciar las mismas situaciones penosas:

Para ir a Bogotá hay que subir por el río Magdalena; es una navegación muy penosa y muy larga, pues dura un mes; sin embargo, se prefiere esta vía al camino por tierra. Antes de embarcarme pedí consejo a mi huésped. En pocas palabras me lo dio, y me pintó con los colores más negros las penalidades que tendría que soportar. Al ver los cinco marineros que debían tripular la piragua, comprendí que no había exagerado. Estaban completamente borrachos. Sus caras salvajes tenían algo de siniestro, que provenía, según después me di cuenta, más del estado en que se hallaban que de su carácter. (...) Mis bogas, así es como se llaman los bateleros del Magdalena, se despidieron...entonando unas letanías a la Virgen. A cada golpe que daban mis bogas con el bichero para hacer avanzar la piragua, perdían el equilibrio y caían unos tras otros al agua. (MOLLIEN, 1944:15).

A renglón seguido Mollien anotaba:

Navegábamos por entre las orillas verdeantes de un río tan ancho como el Senegal, que ofrecía con éste muchos puntos de similitud:la falta de cultivos en sus márgenes, la soledad de las selvas que las cubren, el calor que hace y los negros que se ven, a trechos muy largos, sentados delante de sus cabañas de caña, rodeadas de campos de maíz,...eran otros tantos detalles que me transportaban a Africa. (MOLLIEN, 1944:26). 
No obstante:

El negro del Magdalena,...no tiene el valor viril, la intrepidez ni la fuerza muscular del negro del Senegal; tampoco tiene confianza ciega en su Dios que inspira al otro... El negro africano seguro...no teme ni al diente del cocodrilo, ni al veneno de la serpiente; se lanza sin temor al agua o penetra en la maleza sin miedo alguno. El negro degenerado del magdalena ve enemigos y peligros por todas partes y siempre se acuerda de los sitios donde pereció alguien por imprudencia. (MOLLIEN, 1944:26).

Al respecto de lo que anotó Mollien en su diario sobre los negros del Caribe Colombiano, hay que resaltar un aspecto:a diferencia de otros viajeros y de sus descripciones (Humboldt, Potter Hamilton e incluso Caldas entre otros), Mollien no admiraba en ellos la fuerza y la vitalidad, más bien los veía débiles, cobardes y poco viriles frente a los africanos, a los que, contradictoriamente, les admiraba esos valores que no encontró entre los habitantes del Caribe Colombiano.

Estas y otras concepciones sobre los negros, mulatos y zambos, no eran en lo absoluto sólo las opiniones de este personaje, tal como se ha visto en otras descripciones ya citadas, esta era una percepción constante en sus descripciones e informes de viaje y de gestión administrativa:

(...) a pesar de la prisa que se tiene de llegar cuanto antes, uno se limita a quejarse en su fuero interno, sin enfadarse de las demoras que a cada paso alargan el viaje. Los bogas se detienen siempre que pueden; hoy se trataba de desenterrar huevos de tortuga; sus pesquisas fueron estériles; solo trajeron de su expedición veinticuatro huevos de caimán que estrellaron en seguida (...). (MOLLIEN, 1944:28).

De igual manera, las visiones sobre el comportamiento díscolo de los bogas, y en general de la población negra, mulata y zamba de estas regiones, convenían en algo:Los habitantes en cuestión eran poco dados al trabajo, y proclives al desorden, la lúdica, el gusto desenfrenado por el alcohol, la constante pérdida de tiempo valioso y el poco amor por el trabajo.

Sin embargo, el hecho de que era el viajero quien decidía cuánto tiempo trabajar, los bogas imponían de vez en cuando, lo que Scott identifica como 'una forma de diálogo tras bastidores entre grupos subalternos". En razón de ello, el boga, junto con sus compañeros de travesía, también ejercían un medio de protesta -y de poder, que consistía, en palabras de Mollien:'(en) abandonar al viajero cuando se les impone un trabajo demasiado duro, desertando en el primer lugar habitado donde están seguros de encontrar amigos y protectores.' (Mollien, 1944:33). Estas actitudes que bien se pueden interpretar como una forma de resistencia laboral, se pueden explicar al contrastar la ardua y extenuante tarea a la que debían enfrentarse durante el transcurso del viaje los bogas para llevar a feliz término la labor de viajar por el río. Tarea que no pocos de los viajeros dejaron de admirar debido a la exigencia corporal que conllevaba. En ese sentido, Augusto Le Moyne, uno de los viajeros ya citados reflexionaba sobre esta labor exigente y mal pagada de los bogas de la siguiente forma:

Hasta cierto punto se podría concebir que la profesión de boga la escogiesen únicamente cierta clase de gentes rudas que no tuviesen más que aptitudes para ser cargadores, si por lo menos encontraran en elevados salarios una compensación por el quebranto prematuro de su salud y recursos para la vejez, pero lo que ganan no está, ni mucho menos en proporción con el trabajo agotador que realizan...a más de la alimentación que se reduce a carne ahumada, arroz, plátanos y algunas otras cosas por el estilo igualmente ordinarias. (LEMOYNE, 1969:37-38).

Le Moyne, al igual que otros viajeros se enfrentaba a una realidad que terminaba por contrariar sus posturas sobre la humanidad de los habitantes del Caribe Colombiano. 
Esto es, si bien es cierto que los veía rudos, impúdicos y con poco o ningún recato y en ocasiones también los tildó de borrachos y flojos, también hay que agregar a esta situación, el hecho de que al ver su trabajo tan agotador, termina sintiéndose abrumado, desconcertado e inquieto ante la posibilidad de que este tipo de gentes pudieran llevar a cabo semejante actividad sin mediar sumas equivalentes de dinero, como parte de la retribución necesaria en tal caso. De hecho, la fortaleza de sus palabras parece debilitarse cuando se puede, un poco más adelante en su relato de viaje, leer lo siguiente:

A pesar de la salvajez y del embrutecimiento de los bogas, y del mal trato que algunos viajeros irritados les dan con frecuencia, no he oído decir que aprovechando de su superioridad numérica y de las ocasiones que podrían encontrar a(en) favor del aislamiento de las regiones desiertas donde se viaja, se atrevan contra aquellos o hayan tentado contra sus vidas.... decir verdad los bogas son más brutos que malos o codiciosos; y lo que demuestra que se tenga en ellos alguna confianza es que los negociantes no temen en modo alguno confiar el transporte de las mercaderías, cualquiera que sea su valor, a estos bateleros sin más garantía que un recibo expedido por el patrón. El viajero que sepa dominarse para no maltratarlos, y sobre todo, como lo sé por experiencia, si de vez en cuando les da alguna propina y si lleva consigo bastante cantidad de cigarros y de aguardiente para distribuir entre ellos después de las comidas y muy principalmente después del trabajo de la jornada, se evitará muchas tribulaciones. (LE MOYNE, 1969:39).

81 Un cambio en la forma como se percibe a los habitantes de la región es bastante sintomático, pues de todas formas, ya estos no eran tan desconfiables, como parecían y después de todo, alguna emoción relacionada con la admiración se podía entrever en las palabras de los viajeros. Una reflexión bastante indicativa de lo que se viene sugiriendo en el sentido de que no todos los discursos sobre los habitantes del Caribe Colombiano se ofrecían con la coherencia y sin contradicciones, lo muestra las palabras de otro de los viajeros consultados, en este caso, Pierre D'Espagnat, quien afirmó en medio de sus cavilaciones:

Mientras se cargan a bordo las provisiones de madera, con antelación alineadas y ubicadas sobre el muelle, nos mezclamos con gusto a esas gentes cordiales y corteses, humildes, inteligentes y activas bajo su aspecto de indolencia.(...) Y la comparación se impone entre estas gentes y nuestras plebes europeas sin cesar acuciadas por la miseria desamparada y por la necesidad de trabajo. ¡Qué diferencia a favor de las primeras con su sistema del mínimo de las preocupaciones, del menor número de necesidades materiales !. Hay ciertamente un fondo de filosofía en esa decisión de no trabajar más de lo necesario. En efecto, ¿para qué acumular dinero y matarse a trabajar ? (D’ESPAGNAT, 1971).

Nótese en las reflexiones de D'Espagnat un cambio bastante apreciable sobre los comportamientos ya no de petulancia, orgullo, salvajismo y brutalidad, sino, todo lo contrario, nuestro personaje hasta puede identificar que todos esos epítetos con los que otros viajeros identificaban a los habitantes del Caribe Colombiano, procedían más, como bien se puede apreciar en las negritas de la cita, de un aspecto, es decir, daban la impresión de ser de determinada manera, porque en realidad, siguiendo a D’Espagnat, no lo eran.

\section{CONCLUSIONES}

83 A partir de 1827, comenzó en la ahora República de Colombia, la construcción de un discurso que intentó narrar las grandes gestas, así como los grandes personajes que 
marcaron un hito en la consecución de la nación en el concierto internacional (Múnera, 1998). El intento fue fructífero durante 170 años, pues reprodujo el modelo de historia patria muy practicado en Europa durante el siglo XIX y parte del XX; y en el que las grandes batallas y los grandes luchadores y estrategas tenían un papel central en la narración. La nueva historia contada desde abajo y desde nuevas variables del quehacer historiográfico, así como los estudios interdisciplinarios, han ido resquebrajando este intento y mostrando otras versiones no tan uniformes de la historia nacional.

Colombia ha sido observada desde visiones poco integradoras de los sujetos sociales que la habitan y la han habitado históricamente. Dichas observaciones no tenían que ser de otra forma, dirán algunos, pues se trataba de la imposición de visiones de mundo hegemónicas imperantes desde una Europa cuyo momento histórico extendía sus alas completamente sobre el Mundo (Pratt, 1992). Dichas visiones de mundo han sido una manera de representar a las gentes que han habitado la región del Caribe Colombiano y requieren ser revisadas desde nuevas perspectivas de pensar la historia (Anaya, 2001).

La existencia de una élite criolla que no estuvo en contra de la corona española, sino hasta que esta intentó retomar el poder en las colonias (desamericanizar) y chocó de paso con procesos de cierta autonomía en la toma de decisiones y en el control colonial; produjo unas tensiones que desencadenaron los procesos independentistas (Lynch, 1991). Ahora bien, al ser una colonia de importancia relativa para el imperio, la Nueva Granada se mantuvo muy independiente, pues al estar alejada de los circuitos comerciales de mayor envergadura, como Perú, México y Argentina e incluso Venezuela, ello le ayudó a estar relativamente fuera de la atención de la metrópolis. Esta situación generó el espacio ideal para que las relaciones de poder fueran más relajadas al tiempo que una geografía extremadamente accidentada, ayudó a las provincias y luego regiones, a crecer históricamente hablando, al margen del control más estricto ejercido por la metrópolis en las colonias (Bushnell, 1993).

Una rica e intensa mezcla étnica se abrió paso en las provincias desde el momento inicial de la conquista, especialmente en las costas. Varios factores influyeron para que este proceso de mestizaje se llevara a cabo, entre otros, el hecho de que ante la escasez de mujeres peninsulares en las colonias, los nuevos colonos se unieran inicialmente a las indígenas y posteriormente a las esclavas de origen africano. El resultado ha sido un universo de cruces étnicos sin precedentes. Así, de la unión entre un blanco y una india, salió el mestizo; de un blanco con una negra, el mulato; de una indígena con un negro, un zambo. Posteriormente entre mestizos(as), mulatos(as) y zambos(as) se produjeron otras uniones denominadas "libres de todos los colores" o bien "gentes de la inferior clase" (Florescano, 2000).

Algunas de estas denominaciones llaman la atención por su particular intención de identificar cuán cerca o cuán lejos se estaba de la ansiada búsqueda del blanqueamiento:cuando un blanco se unía a una mulata, sus descendientes daban un "salto" en el proceso, hasta que un buen día eran reputados "blancos". Los descendientes de mestizos entre sí, o bien mulatos entre sí, o zambos entre sí, se denominaban "tente en el aire", pues no había avance y cuando se descendía, es decir, cuando un mulato se unía con una negra, sus descendientes eran reputados como "salta atrás". He aquí la masa de gentes cuyas pigmentaciones de piel, costumbres y clima eran rechazados por no encajar dentro de la uniformidad europea:Los Otros. He aquí los sujetos que no encajaban dentro del ideal de ciudadano para la recién creada nación de Colombia. 


\section{BIBLIOGRAFÍA}

ANAYA Ferreira, NAIR María (2001): La Otredad del Mestizaje:América Latina en la Literatura Inglesa, Fac. de Filosofía y Letras, UNAM, México.

ANDERSON Benedict (1991): Imagined Communities:Reflections on the origins and spread of nationalism.

Verso editions, New York.

ANNINO Antonio, GUERRA François-Xavier (eds.) (2003): Inventando la nación. Iberoamérica Siglo XIX.

México, D.F.:FCE.

ANTEI Georgio (1995): Guia de forasteros:Viajes ilustrados por Colombia 1817-1857, Bogota, Seguros Bolivar.

BALANDIER Georges (1993): El Desorden:La teoría del caos y las ciencias sociales. Elogio de la fecundidad del movimiento. Gedisa, Barcelona.

BARTH Fredrik (2000): Boundaries and connections In:Signifying Identities:Antrhopological perspectives on boundaries and contested values. Anthony P. Cohen (ed). Routledge, London.

BASTIDE Roger: El prójimo y el extraño. El encuentro de las culturas, Buenos Aires, Amorrortu edits. 1973.

BeLl Lemus, Gustavo (1991): Cartagena de Indias de la colonia a la república. Bogota, Colección de historia No.3, Fundacion Simon y Lola Gubereck, Editorial Lealon.

BENITEZ Rojo, Antonio (1996): The Repeating Island. The Caribbean and the Postmodern Perspective. Second Edition. Duke University Press, Durham.

BERIAN Josetxu (1991): Representaciones Colectivas y proyecto de modernidad. Barcelona, Editorial Anthropos.

BITTERLI Urz (1982): Salvajes y Civilizados:El encuentro de Europa y Ultramar. México, Fondo de Cultura Económica.

BUENAHORA Giovanna (2001):“La educación pública femenina en Cartagena, 1870-1900.”

En:Desorden en la plaza. Modernización y memoria urbana en Cartagena. Cartagena, Instituto distrital de cultura.

BUSHNELL David (1993): The Making of Modern Colombia:A Nation in Spite of Itself. University of California Press, Los Ángeles.

CARVAJAL Mario; ROMERo Armando (eds) (1970): Viajeros extranjeros en Colombia, Siglo XIX. CALI, ediciones Carvajal.

CASTAÑEDA Felipe (2002):El indio:entre el bárbaro y el cristiano. Ensayos sobre filosofía de la conquista en Las Casas, Sepúlveda y Acosta. Bogotá, Ceso, Uniandes, y Alfaomega.

CASTRO Carvajal, Beatriz:(ed) (1996): Historia de la vida cotidiana en Colombia. Bogotá, Grupo editorial norma, colección vitral.

CUNIN Elisabeth (2003): Identidades a flor de piel. Lo "negro" entre apariencias y pertenencias: categorías raciales y mestizaje en Cartagena. Bogotá, Instituto Colombiano de Antropología e Historia, Universidad De Los Andes, Instituto Frances De Estudios Andinos Y Observatorio Del Caribe.

DIAZ-GRANAdos Jose (1977): Viajeros extranjeros por Colombia, Bogota, Presidencia de la Republica 
ELIAS, Norbert (1987): Sobre el tiempo. Barcelona. Editorial Crítica.

Félix Bolaños, Álvaro (1994): Barbarie y canibalismo en la retórica colonial. Los indios Pijaos de Fray Pedro Simón. Bogotá, Cerec.

FERNANDEZ Buey, Francisco (1995): La barbarie de ellos y de los nuestros. Paidós, Barcelona.

FLORESCANO, Enrique (2000): Etnia, Estado y Nación. Ensayo sobre las identidades colectivas en México. Taurus, México.

GARLIZ Fitz, F. y Jimenez Alcazar, J.F. (eds) (2012):La historia peninsular en los espacios de frontera, las "extremaduras históricas" y la transierra" (siglos XI-XV), Murcia, Editum.

GARLAN Allen (1984):“The roots of biological determinism." En:Journal of the history of biology. HOBSBAWM Eric (2000): Naciones y Nacionalismos desde 1870. Crítica, Barcelona.

HURBON Laënnec (1993): El Barbaro Imaginario, Mexico, Fondo De Cultura Economica.

JARAMILLO Uribe, Jaime (2002):"La visión de los Otros:Colombia vista por observadores extranjeros en el siglo XIX." En:Historia, Sociedad y Cultura. Ensayos y conferencias. Obras Completas de Jaime -Jaramillo Uribe. Bogotá, Ceso, Uniandes, Banco de la República, Icanh, Colciencias y editorial Alfaomega.

LEONARD Irving A. (1992): Viajeros por la América Latina Colonial. México, Fondo de Cultura Económica.

LIPPINCOTT Kristen; ECO, Humberto y GOMBRICH, E.H. et al (2000): El tiempo a través del tiempo. Barcelona. Grijalbo Mondadori.

LYNCH John (1991): Las revoluciones hispanoamericanas, En:Historia de América Latina. Leslie Bethel (ed). Editorial Crítica, Barcelona, Volumen V.

MARTINEZ Reyes, Gabriel (1986): Cartas de los obispos de Cartagena durante el periodo hispánico. 1534-1820. medellin, editorial zuluaga.

MORNER, Magnus (sin fecha): Relatos de Viajeros Europeos como fuentes para la Historia Latinoamericana desde el siglo XVIII hasta 1870. Conferencia dictada en Wolfenbuttel (Alemania). Documento mecanografiado.

MUNERA Alfonso (1998): El ilustrado Francisco José de Caldas y la creación de una imagen de la nación. En: Cuadernos de Literatura, No. 7-8, Bogotá, Pontificia Universidad Javeriana, Facultad de Ciencias Sociales, enero-diciembre de 1998.

MUNERA Alfonso (1998): Las clases populares en la historiografía de la independencia de Cartagena. En:Calvo Stevenson, Haroldo y Meisel Roca, Adolfo (ed):Cartagena de Indias y su Historia. Bogotá, Universidad Jorge Tadeo Lozano, seccional del Caribe y Banco de la República.

MUNERA Alfonso (1998): El Fracaso de la Nación:Región, Clase y Raza en el Caribe Colombiano (1717-1810). Banco de la Republica, El Ancora editores, Bogotá.

NICHOLS Theodore (1973): Tres Puertos de Colombia. Bogotá, Banco Popular Ed. NOGUERA Mendoza Aníbal (1980). Crónica grande del río Magdalena. Bogotá, Fondo Cultural Cafetero, Editorial Sol y Luna.

PEÑAS Galindo David (1991): Los Bogas de Mompox. Historia del Zambaje. Bogotá, Tercer Mundo Editores.

PRATT Mary Louis (1992): Imperial Eyes:Travel Writing and Transculturation. Routledge, London. 
RAMOS Junior Dernibal (2013): Narrativa, Fronteriras e Nacao:Caribe Colombiano. En:Revista Brasileira do Caribe, vol. XIV, núm. 27, julio-diciembre.

RIVERA Nieves Irma (1999): Cambio de cielo. Viaje, sujeto y ley. San Juan, Taller de Ciencias Humanas, Degi, Universidad de Puerto Rico y Postdata Ediciones.

scotT James C. (1985): Weapons of the Weak. Everyday forms of peasant resistance. Yale University Press, London.

SOlano Sergio Paolo (2003): Puertos, Sociedad y Conflictos en el Caribe Colombiano, 1850-1930. Bogotá, Observatorio del Caribe Colombiano, Ministerio de Cultura y Universidad de Cartagena.

SOLANO Sergio Paolo (1998): De Bogas a Navegantes. Los trabajadores del transporte por el Rio Magdalena. 1850-1930. En:Historia Caribe, No.3.

THOMPSON Edward (1979): Tradición, Revuelta y Conciencia de Clase. Estudios sobre la sociedad preindustrial. Critica, Barcelona.

TODOROV Zvetan (1991):Nosotros y los Otros, México, Siglo XXI editores.

TODOROV Zvetan (2000): La conquête de l'amérique. La question de l'autre. Paris, editions du seuil, 1982. Hay Trad. Al español: La conquista de América, el problema del otro. México, siglo XXI editores.

WEBER Max (1978): La ética protestante y el espíritu del capitalismo. Barcelona, Editorial Paidós.

ZEA Leopoldo (1990): Discurso desde la marginación y la barbarie. México, Fondo de Cultura Económica.

\section{Fuentes}

ABBAD y LASSIERRA, Fray Iñigo:Historia Geográfica, Civil y Natural de la isla de San Juan Bautista de Puerto Rico, Río Piedras, Editorial de la Universidad de Puerto Rico, 1979.

CALDAS Francisco José de: Estado de la Geografía del virreinato de Santa fe de Bogotá, con relación á la economía y al comercio. En:Posada, Eduardo (comp):Obras de Caldas. Biblioteca de Historia Nacional Vol. IX. Bogotá, Imprenta Nacional, 1912.

CALDAS Francisco José de:Obras Completas, Bogotá, Universidad Nacional de Colombia, 1966.

Carta de Dn. Manuel de Sosa Betancourt al Obispo con fecha del 4 de abril de 1764 En:Martínez Reyes, Gabriel:Cartas de obispos de Cartagena durante el período hispánico. 1534-1820. Medellín. Editorial Zuluaga, 1986.

COCHRANE Charles Stuart:Viajes por Colombia 1823 y 1824. Diario de mi residencia en Colombia. Bogotá, Biblioteca V Centenario, Colcultura, 1994.

Colección Trujillo: Recopilación Diplomática relativa a las colonias españolas y francesas de la isla de Santo Domingo (1640-1701). Editorial La Nación, C.T, 1944.

D'ESPAGNAT Pierre:Recuerdos de la Nueva Granada. Bogotá, Biblioteca Scharing Corporation u.s.a de Cultura Colombiana. Serie 91. Ediciones Guadalupe, 1971.

K, George D.: An Account of the Present State of the Island of Puerto Rico. San Juan, Academia Puertorriqueña de la Historia, 2002.

VON HUMBOLDT Alejandro: Viaje a las regiones equinocciales del nuevo continente. Caracas:Ediciones del ministerio de educación,2 Tomos, 1956.

VON HUMBoLDT Alejandro: Del Orinoco al Amazonas. Barcelona:Editorial Labor, (1982). 
VON HUMBOLDT Alejandro: Aspecs of Nature. London:Longman, Brown and Longmans printed, In two volumes. 1849.

Informe del obispo de Cartagena, Don José Fernández Díaz de la Madrid:La Universal relajación y corrupción de las costumbres de los fieles de la provincia de Cartagena en el año de 1781. En:Bell Lemus, Gustavo:Cartagena de Indias de la colonia a la república. Bogotá:Col. de historia No.3. Fundación Simón y Lola Gubereck. 1991.

LEDRU André Pierre: Viaje a la isla de Puerto Rico, Río Piedras, Ediciones del Instituto de Literatura Puertorriqueña, 1957.

LE MOYNE Auguste: Viaje y estancia en la Nueva Granada. Bogotá, Biblioteca Scharing Corporation U.S.A de Cultura Colombiana. Serie 91. Ediciones Guadalupe, 1969.

MOLLIEN Gaspard Théodore:Viaje por la república de Colombia en 1823. Imprenta Nacional, Bogotá, 1944.

MOREAU DE SAINT MERY M.L.:Description Topographique, Physique, Civile, Politique et Historique de la Partie Française de lile de Saint-Domingue, Filadelfia, 1797.

MUTIS Jose Celestino: Viaje a Santa Fe. Madrid, Crónicas de América 66. Historia 16 edit., 1991.

POTTER HAMILTON John: Viajes por el interior de las provincias de Colombia. Bogotá, Comisión V Centenario del descubrimiento. Colcultura, editorial presencia, 1993.

RECLUS Eliseo:Viaje a la sierra nevada de Santa Marta. Bogotá, Comisión V Centenario del descubrimiento. Colcultura, Ediciones Tercer Mundo, 1992.

ROTHLISBERGER, Ernts: El Dorado. Bogotá, Biblioteca V centenario, Viajeros por Colombia, Colcultura, 1993.

\section{Imágenes}

Biblioteca Luis Ángel Arango. Sala de libros raros y manuscritos. Bogotá, Colombia. 
www.delcampe.net.

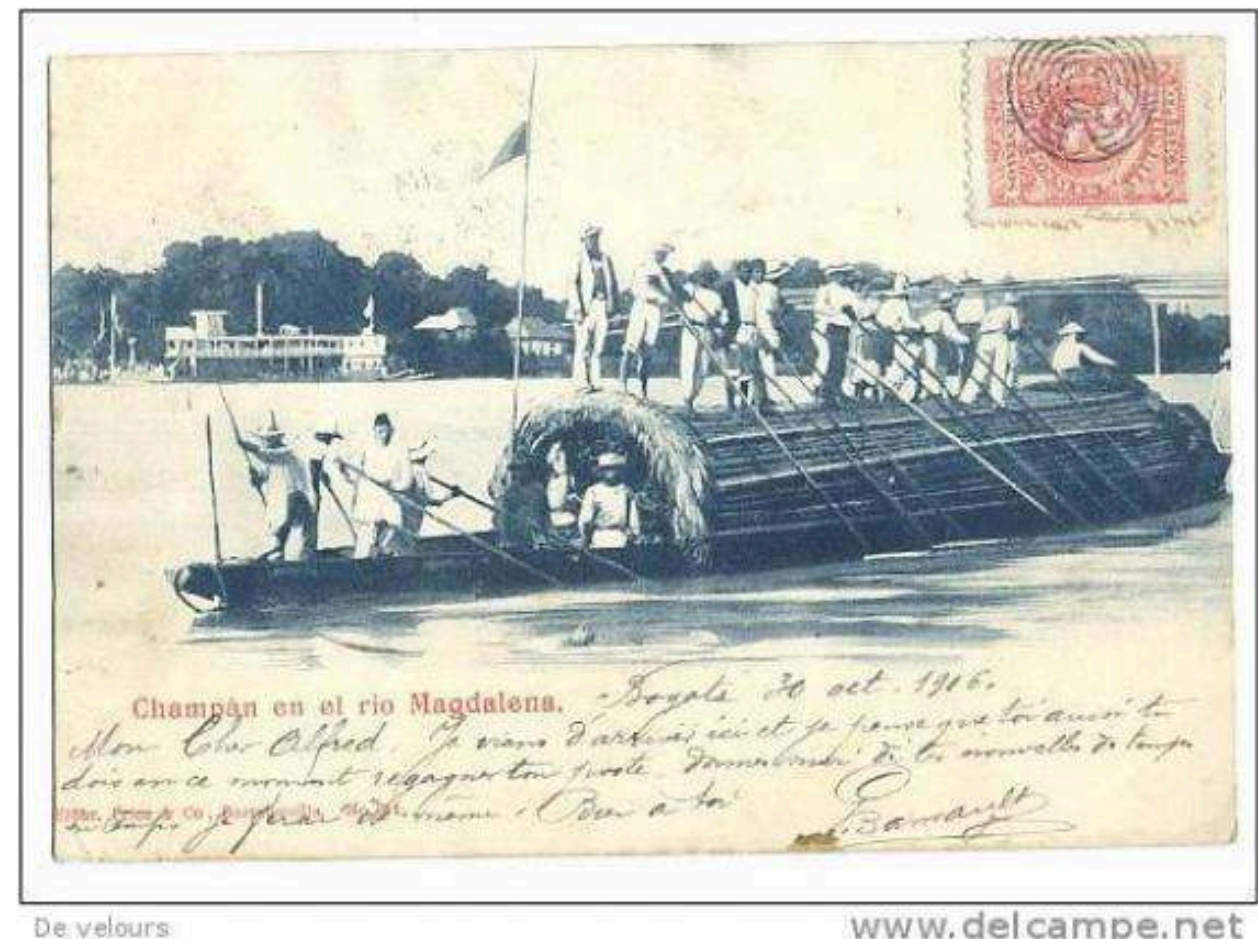

Algunas de estas denominaciones llaman la atención por su particular intención de identificar cuán cerca o cuán lejos se estaba de la ansiada búsqueda del blanqueamiento:cuando un blanco se unía a una mulata, sus descendientes daban un "salto" en el proceso, hasta que un buen día eran reputados "blancos". Los descendientes de mestizos entre sí, o bien mulatos entre sí, o zambos entre sí, se denominaban "tente en el aire”, pues no había avance y cuando se descendía, es decir, cuando un mulato se unía con una negra, sus descendientes eran reputados como "salta atrás". He aquí la masa de gentes cuyas pigmentaciones de piel, costumbres y clima eran rechazados por no encajar dentro de la uniformidad europea:Los Otros. He aquí los sujetos que no encajaban dentro del ideal de ciudadano para la recién creada nación de Colombia.

\section{RESÚMENES}

Este artículo analiza las descripciones que sobre la región, su clima, flora y fauna, así como de sus habitantes dejaron plasmadas en sus diarios y memorias de viajes los extranjeros que viajaron por el Caribe Colombiano a finales del siglo XVIII y principios del XIX. Especial interés revisten las imágenes que sobre los habitantes y la región del Caribe Colombiano dejaron plasmadas en sus escritos los personajes estudiados, en la medida en que sus descripciones crearon el Otro en relación con sus lugares de procedencia y de la Nación Colombiana ad portas.

Cet article analyse les descriptions sur la région des Caraïbes colombiennes, son climat, sa flore et sa faune, ainsi que ses habitants, via les traces laissées par les étrangers qui ont parcourus les Caraïbes. Dans ces journaux et mémoires de la fin du xviiie et début du xixe siècle, nous pouvons remarquer un intérêt particulier porté aux images de la population et de la région des Caraïbes colombiennes. Également dans ces écrits s'expriment les personnages étudiés et ces descriptions produisent l'Autre par rapport à leurs villes natales et à la nation colombienne. 
ÍNDICE

Mots-clés: Caraibes colombiennes, histoire, voyageurs, population, altérité

Palabras claves: Caribe colombiano, historia, viajeros, población, otredad

\section{AUTOR}

\section{LEGUIS A. GÓMEZ}

Candidato a doctorado en historia por la Universidad de La Laguna, Tenerife, España y magister en historia por la Universidad de Puerto Rico. 